\title{
A Survey on New Product Development, Market Orientation and Organizational Financial Performance: A Case Study on Selected Beer Factories in Ethiopia
}

\author{
Nigist Kelemu \\ Department of Marketing Management, College of Business and Economics, Bahir Dar University, Bahir Dar, Ethiopia \\ E-mail: nigistkelemu@yahoo.com/nigistkelemu92@gmail.com
}

\begin{abstract}
Survey was conducted to investigate the association between market orientation, production process, product performance, organizational performance and financial performance. The purpose of this survey was to investigate relationships among market orientation, launch strategy, product performance, organizational performance, profitability and financial performance. Target populations were employees of selected Ethiopian beer factories BGI Ethiopia who are currently consuming the product; from which sample was determined through judgmental sampling method. Inquired data was collected via survey questionnaire, linear regression analysis was conducted to check the relationship among leading variable. Finally it was found that firms' profitability and financial performance are being influenced by market orientation, launch strategy, product performance and organizational performance. Firms are recommended to focus on enhancing market orientation, launch strategy, product performance and organizational performance to boost profitability and financial performance.
\end{abstract}

Keywords: Market orientation, Product performance, profitability, organizational performance

\section{INTRODUCTION}

According to Deshpande' et al. (1993); Kohli and Jaworski (1990); Narver and Slater (1990, 1998) Market orientation is a business culture that (1) places the highest priority on the profitable creation and maintenance of superior value for customers while considering the interest of other stakeholders; (2) provides norms for behaviours regarding the organizational generation, dissemination and responsiveness to market information. Moreover, Hunt and Morgan (1995) state that a market-oriented culture produces a sustainable competitive advantage and, thus, superior long-run organizational performance. In line with this reasoning, Homburg and Pflesser (2000) extensively have pursued an understanding of the link between market orientation and performance.

Ansoff, (1987) defined Product development as the focus on the needs of the current customers and the wider customer markets. Kotler (2000) says in product development a firm remains in its present markets but develops new products for these markets. The view that new products are helpful to the financial health of sponsoring firms is well argued by scholars. Schumpeter (1934), for instance, opined that innovative new products when first introduced face limited direct competition and, as a result, allow relatively high profits to sponsoring firms. Over time these high profits are likely to disappear because of imitation and competition, he argued, but firms that keep on introducing innovative new products may be able to have high profitability for a sustained period. Large and growing literature supports the positive correlation between innovation and firm profitability. The number of innovations produced by firms had a positive effect on their operating profit margin, Geroski et al. (1993). According to Clark and Fujimoto (1991) performance in a development project is determined by a firm's product strategy and by its capabilities in overall process and organization.

They further claim that firms' products help to shape the market environment; the nature of the market environment changes as consumers and competitors learn from new products and services. Goedhuys and Veugelers (2008) stated that Innovative performance is an important driver for firm growth in particular the combination of product and process innovations that significantly improves firm growth. Furthermore, Anurag and Nelson, (2004) argued that Financial markets may be attuned sharply to product development outcomes in publicly traded firms. Hover there are different studies conducted on different countries on this issues in different perspectives, in Ethiopian context as far as the researchers knowledge there is no research works directly or indirectly conducted on this issues. Therefore, the intent of this study seeks to address the intervening effect of new product development in relation with market orientation on organizational financial performance: the case of Ethiopian Beer Factories.

\section{RESEARCH FRAMEWORKS}

\section{A. Company Performance}

Zahra \& Hayton (2008) established that the literature on performance is very extensive, but that it shows a lack of consensus as to the meaning of the term. Brush \& Vanderwerf (1992) point out; that the use of the term "performance" by researchers includes many constructs measuring alternative aspects of performance. 
This is consistent with the finding of Murphy et al. (1996) who, after a comprehensive literature review, were able to isolate a total of 71 different measures of performance. Hansen, (2010) In spite of this apparent abundance, the vast majority of studies has used financial measures of performance.

According to Pandian, et al., (2006); Sapienca et al., (1988). The raison d'être for this fixation with financial performance measures, is found partly in the fact that financial performance is at the core of the organizational control systems and partly in that it is one of the most easily quantifiable measuring instruments.

However, this has caused empirical research to rely on a narrow set of accounting measures of financial performance, such as return on investment (ROI), return on assets (ROA), or earnings per share.

On the other hand Pérez-Luñoa et al., (2011) stated that the innovation management organization (IMO) is responsible for developing new products and technologies.

Science and technology from the external environment are combined with the company's in-house skills, knowledge and competencies to develop new products and technologies.

The responsibilities that fall within the domain of innovation management encompass research and development (R\&D). For this reason, R\&D consists of those activities and responsibilities ranging from understanding progressive technology to generating ideas to developing new products and technologies.

\section{B. Conceptual Framework and Hypothesis Development}

Researcher will use the following conceptual framework as a study guideline. Conceptual Framework and Hypotheses.

Relationships across the building blocks in this study: market orientation, new product advantage, the proficiency in launch activities (market testing, launch budgeting, launch strategy, and launch tactics), new product

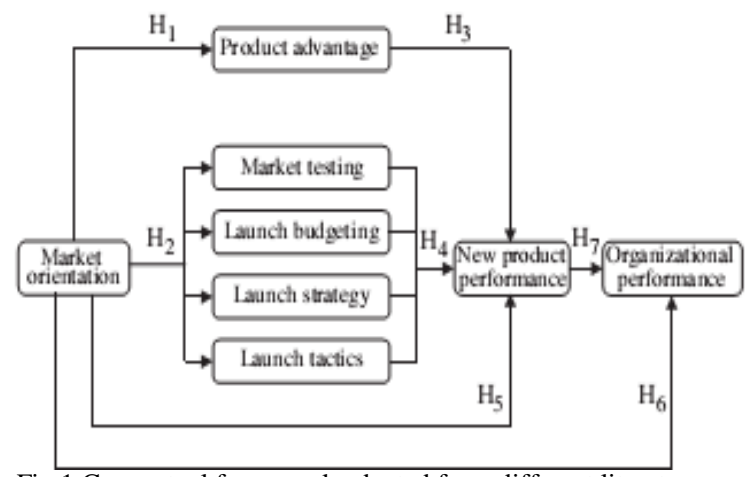

Fig.1 Conceptual framework adapted from different literature performance, and organizational performance. It is proposed here that a market-oriented culture is related positively to product advantage and launch proficiency. It also is posited that the ability of market-oriented firms to develop and to launch products that fit customer needs leads to superior new product performance.

Superior new product performance subsequently affects organizational performance. A market-oriented culture, however, also can influence the proficiency in other marketing activities (i.e., pricing, distribution, and promotion) and other NPD activities (i.e., predevelopment and development) besides the launch activities.

Therefore, market orientation also is hypothesized to have a direct influence on new product performance and organizational performance. Next, the hypotheses will be developed.

\section{The Relationship between Market Orientation and Product Advantage}

According to Calantone and di Benedetto (1988) Product advantage refers to the benefits that customers get from the new product. Lukas and Ferrell; (2000) indicated that the influence of a market-oriented culture on product advantage is a subject of debate.

Bennett and Cooper; (1981) have suggested that a strong market-oriented culture may lead to imitations and to marginally new products.

Christensen and Bower (1996) add that listening too closely to customers can constitute a barrier to commercializing new technology and can lead to less competitiveness. In contrast to this, Slater and Narver $(1998,1999)$ indicated that there is strong conceptual and empirical evidence that a market oriented culture enhances the creation of superior value for customers relative to competitors.

In addition, Baker and Sinkula (1999a); Pelham and Wilson (1996); Slater and Narver (1994a) the empirical evidence that market orientation has a positive relationship with new product success acknowledges that market oriented firms develop products with greater advantage over the competition because product advantage is the number-one factor affecting new product performance.

Finally, Atuahene-Gima; (1996) stated that the proposition that a market-oriented culture leads to greater customer satisfaction and repeat business also implicitly acknowledges that market-oriented firms develop products with greater advantage over competition. Therefore, it is hypothesized that 
H1: $\quad$ Market orientation of the firm is positively related with product advantage.

H2: Market orientation of the firm is positively related with company's proficiency on (1) market testing, (2) launch budgeting, (3) launch strategy, and (4) launch tactics.

H3: Product advantage is positively related with new product performance.

H4: Company's proficiency on (1) market testing, (2) launch budgeting, (3) launch strategy, and (4) launch tactics, is positively related with new product performance.

H5: Firm's market orientation is positively related with new product performance.

H6: Firm market orientation is positively related with organizational performance.

H7: New product performance is positively related with organizational performance.

\section{METHODOLOGY}

\section{A. Research Design}

The research design used under this study was crosssectional survey type of paradigm. A cross-sectional survey offers the opportunity to collect data across different beer factories and test this relationship.

With respect to the time period over which data was collected, across the various beer companies, a crosssectional survey was found appropriate.

Furthermore, it was ideal because the researcher intended to collect descriptive data that was accorded statistical treatment to allow for hypothesis testing to come up with objective conclusions (Cooper and Schindler, 2003).

\section{B. Target Population}

This study considered all employees of selected Ethiopian beer factories (BGI Ethiop, Meta ABO and Harar Brewery) who are currently consuming the product. Therefore the target respondents of the study were all employees of Ethiopian beer enterprises.

\section{Sampling Design and Sample Size Determination}

The researcher used purposive/judgmental sampling method to determine the sample size of the research.

It was preferred purposely to include selected employees of each beer factories who are currently drinking beer products. This study took employees of each factory as respondents because researcher assumed that these individuals have better knowledge regarding the products and organization.
This research project considered purposefully selected 3 beer factories, BGI Ethiop (Amber, Castel and St. George), Meta ABO (Meta beer and Meta premium) and Harar Brewery (Harar beer and Hakim stout) in Ethiopia.

Researcher took all employees of each beer factories who currently drinks beer. These beer factories are selected because they have different products as compared with other beer factories.

\section{Data sources and Data Collection Instruments}

Researcher used both primary and secondary data. Primary data was collected from the employees of Ethiopian beer factories using survey Questionnaire.

Secondary Data was gathered from company audited financial statements operating the last 5 years. Survey questionnaire and audited financial statements were used to gather the relevant quantitative data.

Interview was also conducted for general managers in each firm to collect qualitative data which was used to triangulate the research framework. The constructs were measured using five-point multi-item scales drawn from previous studies.

\section{E. Data Analysis}

In this study, researcher is referring mixed approach hence both quantitative and qualitative data analysis techniques was employed.

Linear regression analysis was conducted to measure the relationship between the dependant and independent variables.

Qualitative data was used to triangulate the structure of the study. The study also investigated the cause and effect relationship between mediating variables.

\section{RESULTS AND DISCUSSION}

\section{A. Data Sample Information}

A total of 240 questionnaires were distributed at selected Ethiopian beer factories (BGI Ethiop, Meta ABO and Harar Brewery) Out of which 227 questionnaires were returned, which researchers used as an input for analysis to present the findings and draw conclusion.

Further the data analysis was performed to reach the findings; hence the analysis, results and discussions are presented as follows. 
TABLE I DISTRIBUTION OF BACK GROUND VARIABLE (N=227)

\begin{tabular}{|c|c|c|c|c|c|}
\hline \multicolumn{2}{|r|}{ Gender } & Frequency & Percent & $\begin{array}{c}\text { Valid } \\
\text { Percent }\end{array}$ & $\begin{array}{c}\text { Cumulative } \\
\text { Percent }\end{array}$ \\
\hline \multirow{3}{*}{ Valid } & Female & 91 & 40.1 & 40.1 & 40.1 \\
\hline & Male & 136 & 59.9 & 59.9 & 100.0 \\
\hline & Total & 227 & 100.0 & 100.0 & \\
\hline \multicolumn{2}{|c|}{$\begin{array}{c}\text { Educational Level Of } \\
\text { Respondents }\end{array}$} & Frequency & Percent & $\begin{array}{c}\text { Valid } \\
\text { Percent }\end{array}$ & $\begin{array}{c}\text { Cumulative } \\
\text { Percent }\end{array}$ \\
\hline \multirow{6}{*}{ Valid } & $\begin{array}{l}\text { Reading and } \\
\text { writing }\end{array}$ & 3 & 1.3 & 1.3 & 1.3 \\
\hline & $\begin{array}{l}\text { Complete grade } \\
\text { ten/ twelve }\end{array}$ & 7 & 3.1 & 3.1 & 4.4 \\
\hline & Diploma holder & 54 & 23.8 & 23.8 & 28.2 \\
\hline & Degree holder & 77 & 33.9 & 33.9 & 62.1 \\
\hline & $\begin{array}{l}\text { Masters and } \\
\text { above }\end{array}$ & 86 & 37.9 & 37.9 & 100.0 \\
\hline & Total & 227 & 100.0 & 100.0 & \\
\hline
\end{tabular}

Table I reveals distribution of respondent's background information of the first variable; gender of the respondent which indicate that $91(40.1 \%)$ of the respondent are female while $136(59.9 \%)$ of them are male. Hence most of the respondent in this project are male. Beside to this the analysis result of educational background of the study respondents which indicates that $3(1.3 \%)$ of the respondents are able only reading and writing, $7(3.1 \%)$ of them are complete grade ten, 54(23.8\%) of them are diploma holders, $77(33.9 \%)$ of them are degree holder and $86(37.9 \%)$ of the respondents are master holder and above. This indicates that most of the study respondents are degree and master holders.

\section{B. Measuring the Association between Basic Study Variable and Researches Constructs}

This study was conducted to investigate the relationship between market orientation, new product performance, and organization performance and organization profitability. Therefore in this part of the study, a keen attention is given to measure the relationship among the leading constructs (market orientation, new product performance, and organization performance and organization profitability). So here the analysis result and discussion of basic variables are displayed below.

TABLE II DESCRIPTION OF WORKING VARIABLES

\begin{tabular}{|c|c|c|}
\hline $\begin{array}{c}\text { No.of } \\
\text { variables }\end{array}$ & Main constructs & Description \\
\hline 4 & Market orientations & $\begin{array}{l}\text { customer preference, market testing before launching the product, distributions } \\
\text { strategy and quality of distribution system }\end{array}$ \\
\hline 3 & Product advantage & $\begin{array}{l}\text { customer's attitude on product quality, product effectiveness/consumer } \\
\text { perception, consumer expectation, customer satisfaction }\end{array}$ \\
\hline 3 & $\begin{array}{l}\text { New product } \\
\text { performance }\end{array}$ & Product compatibility, trial ability and observe-ability \\
\hline 4 & $\begin{array}{l}\text { Organizational } \\
\text { performance }\end{array}$ & $\begin{array}{l}\text { Competition capability sales efficiency, market share advantage, profit } \\
\text { efficiency }\end{array}$ \\
\hline
\end{tabular}

Table III indicates the analysis result of market orientation related variables mainly customer preference, market testing strategy, distribution strategy and quality of distribution system in relation with product advantage to test the first hypothesis. Analysis result of all market related variables related with product advantage are positive which indicates that the first hypothesis is accepted. On the other hand customer preference, market testing strategy, distribution strategy and quality of distribution strategy in relation with firms proficiency in launching activity are positively related which indicates that the second hypothesis is also accepted. 
TABLE III ANALYSIS OF MAJOR VARIABLE TESTING FIRST AND SECOND HYPOTHESIS

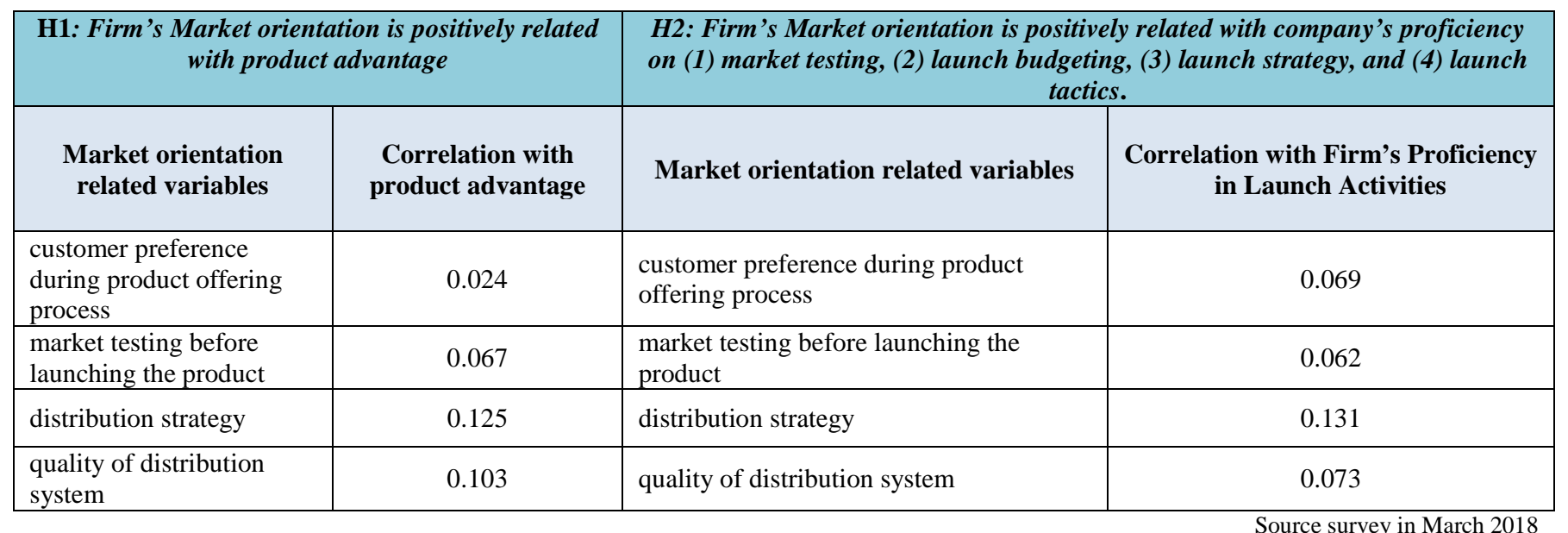

TABLE IV ANALYSIS OF MAJOR VARIABLE TESTING THIRD AND FOURTH HYPOTHESIS

\begin{tabular}{|c|c|c|c|}
\hline \multicolumn{2}{|c|}{$\begin{array}{l}\text { H3: Product advantage is positively related with new } \\
\text { product performance. } m \text { 's Market orientation is positively } \\
\text { related with product advantage }\end{array}$} & \multicolumn{2}{|c|}{$\begin{array}{l}\text { H4: Company's proficiency on (1) market testing, (2) launch } \\
\text { budgeting, (3) launch strategy, and (4) launch tactics, is positively } \\
\text { related with new product performance. }\end{array}$} \\
\hline $\begin{array}{l}\text { Product advantage related } \\
\text { variables }\end{array}$ & $\begin{array}{c}\text { Correlation with } \\
\text { Product performance }\end{array}$ & launch activities related variables & $\begin{array}{c}\text { Correlation with product } \\
\text { performance }\end{array}$ \\
\hline $\begin{array}{l}\text { customer's attitude on product } \\
\text { quality }\end{array}$ & 0.024 & Testing compatibility of physical product & .144 \\
\hline $\begin{array}{l}\text { product effectiveness/consumer } \\
\text { perception }\end{array}$ & .098 & Assigning budget for strategy implementation & .105 \\
\hline consumer expectation & .078 & $\begin{array}{l}\text { Answering the what, where, when, and why to } \\
\text { launch }\end{array}$ & .027 \\
\hline $\begin{array}{l}\text { customer satisfaction relative to } \\
\text { expectation }\end{array}$ & .123 & How to launch the new product & .022 \\
\hline
\end{tabular}

Table IV shows the analysis result of customer attitude towards product quality, customer perception, customer expectation and customer satisfaction in relation with product performance which implies that product advantage is positively related with product performance hence the third hypothesis is accepted.

Besides compatibility of physical product, implementation strategy, product type, place and reason to launch the product are positively related with product performance; hence the fourth hypothesis is also accepted.

Table $\mathrm{V}$ reveals analysis result done to assess the relationship among customer preference, market tasting strategy, distribution strategy, quality of distribution strategy and new product performance which results that they are positively related;

Hence the fifth hypothesis is accepted. Besides customer preference, market tasting strategy, distribution strategy, and quality of distribution strategy are positively related with organizational performance which indicates that the sixth hypothesis is also accepted.

Table VI shows analysis output of the relationship among product compatibility, product trial-ability, product observeability and organizational performance; which indicates that all variables are positively related and the last hypothesis is accepted. 
TABLE V ANALYSIS OF MAJOR VARIABLE TESTING FIFTH AND SIXTH HYPOTHESIS

\begin{tabular}{|c|c|c|c|}
\hline \multicolumn{2}{|c|}{$\begin{array}{l}\text { H5: Firm's market orientation is positively related } \\
\text { with new product performance. }\end{array}$} & \multicolumn{2}{|c|}{$\begin{array}{c}\text { H6: Firm market orientation is positively related with } \\
\text { organizational performance. }\end{array}$} \\
\hline $\begin{array}{l}\text { Market orientation related } \\
\text { variables }\end{array}$ & $\begin{array}{l}\text { Correlation with } \\
\text { new product } \\
\text { performance }\end{array}$ & Market orientation related variables & $\begin{array}{c}\text { Correlation } \\
\text { with } \\
\text { organizational } \\
\text { performance }\end{array}$ \\
\hline $\begin{array}{l}\text { customer preference during } \\
\text { product offering process }\end{array}$ & .068 & $\begin{array}{l}\text { customer preference during product offering } \\
\text { process }\end{array}$ & .085 \\
\hline $\begin{array}{l}\text { market testing before launching } \\
\text { the product }\end{array}$ & .120 & market testing before launching the product & .178 \\
\hline distribution strategy & .112 & distribution strategy & .212 \\
\hline quality of distribution system & .151 & quality of distribution system & .233 \\
\hline
\end{tabular}

TABLE VI ANALYSIS OF MAJOR VARIABLE TESTING SEVENTH HYPOTHESIS

\begin{tabular}{|c|c|}
\hline $\begin{array}{c}\text { H7: New product performance is positively related with organizational } \\
\text { performance }\end{array}$ \\
\hline $\begin{array}{c}\text { Product performance related } \\
\text { variables }\end{array}$ & $\begin{array}{c}\text { Correlation with organizational } \\
\text { performance }\end{array}$ \\
\hline Compatibility & .101 \\
\hline Trial-ability & .132 \\
\hline Observe-ability & 089 \\
\hline
\end{tabular}

\section{CONCLUSIONS AND RECOMMENDATIONS}

\section{A. Conclusions}

This study was conducted to investigate, describe and report the association between market orientation, in terms of market itself, customer, competition, production process, productivity product performance, organizational performance and profitability. Hence after gathering the inquired data from the target respondents using a survey questionnaire, linear regression analysis was made using statistical package for social science to assess the relationship between the independent variables. Accordingly researchers conclude the following based on the analysis results.

1. Market orientation; company's ability to consider customer preference during new product production process, market testing before launching the product, distributions strategy and quality of distribution system have significant influence on company's product advantage

2. Organization's proficiency in market testing, launch budgeting, launch strategy, and launch tactics are positively related with its market orientation strategies.

3. Product advantages in terms of customer's attitude on product quality, product effectiveness/consumer perception, consumer expectation, customer satisfaction relative to expectation are positively influences new product performance.

4. Market orientation strategies exert positive influence on product performance.

5. Market orientation is positively related with company's competitive capability, sales efficiency and profitability.

\section{B. Recommendation}

1. BGI, Meta Abo and Harar breweries do not have effective marketing orientation, product developments and launching strategies that lead reduction in sales profit and performance. Hence, due attentions should be given towards improving existing market orientation, product development and launching strategies so that organizational performance can be boosted in a competitive environment.

\section{REFERENCES}

[1] Hunt, S.D. \& Morgan, R. (1995). "The Comparative Advantage Theory of Competition”, Journal of Marketing, 59 (2), 1-15.

[2] Kohli, A.K. and Jaworski, B.J. (1990) Market orientation: the construct, research propositions and managerial implications .Journal of Marketing 54, April, 1-18.

[3] Homburg and Pflesser (2000) A systematic literature review of internal capabilities for enhancing eco-innovation performance of manufacturing firms,209. 
[4] H. Igor Ansoff (1987), 'Concept of Strategy', in Corporate Strategy, London: Penguin Books, 100-116

[5] Kotler, P. (2000) Marketing Management the Millennium Edition. Person Prentice Hall, Upper Saddle River.

[6] Schumpeter, J.A., 1934 (2008), the Theory of Economic Development: An Inquiry into Profits, Capital, Credit, Interest and the Business Cycle, New Brunswick (U.S.A) and London (U.K.): Transaction Publishers.

[7] Geroski, P, M., Machin, S.and Reenen, J. (1993). The Profitability of Innovating Firms. Rand Journal of Economics24 (2),198-211.

[8] Clark, K. B. and Fujimoto, T. (1991). Product Development Performance: Strategy, Organization, and Management in the World Auto Industry. Boston: Harvard Business School Press.

[9] Goedhuys, M. and Veugelers, R. (2008). Innovation strategies, process and product innovations and growth: Firm-level evidence from Brazil. Department of Managerial Economics, Strategy and Innovation (MSI)

[10] Anurag, S. and Nelson, L. (2004). Linking Product Development Outcomes to Market Valuation of the Firm: The Case of the U.S. Pharmaceutical Industry. Journal of product Innovation Management

[11] Dirk Heremans, 2007. "Corporate governance issues for banks. A financial stability perspective," Working Papers of Department of Economics, Leuven ces0707, KU Leuven, Faculty of Economics and Business (FEB), Department of Economics, Leuven.

[12] Rutagi . R (1997).Performance of parastatal Organizations in Uganda.

[13] Namisi. R.N. (2002). Board of Directors Composition, Team Processes and Organizational performance of selected financial institutions in Uganda. Unpublished Research Dissertation submitted in partial fulfillment for the award of a degree at Makerere University.

[14] Epstein (2003).Relations Between Continuous Performance Test Performance Measures and ADHD Behaviors VL - 31 Journal of abnormal child psychology

[15] Zahra, S., \& Hayton, J. (2008). The Effect of International Venturing on Firm Performance: The Moderating Influence of Absorptive Capacity. Journal of business venturing, 2008(23), 1995-220.

[16] Brush, C. G., \& Vanderwerf, P. A. (1992). A comparison of methods and sources for obtaining estimates of new venture performance. Journal of Business Venturing, 7(2), 157-170.

[17] Murphy, G. B., Trailer, J. W., \& Hill, R. C. 1996. Measuring performance in entrepreneurship research. Journal of Business Research, 36: 15-23.

[18] Pérez-Luñoa, A., Wiklundb, J., \& Cabrera, R. A. (2011). The dual nature of innovative activity: How entrepreneurial orientation influences innovation generation and adoption. Journal of Business Venturing, 26(5), 555-571

[19] Kotler, P. (2003) Marketing Management. 11th Edition, PrenticeHall, Upper Saddle River.

[20] Pandian, J.R, Thomas, H. Furrer, O. \& Bogner, W.C. (2006). Performance differences across strategic groups: an examination of financial market-based performance measures. Strategic Change, 15(6), 373-383.

[21] Calantone and di Benedetto. (1988). An Integrative Model of the New Product Development Process An Empirical Validation Pages ,201-215

[22] Lukas, B.A. and Ferrell, O.C. (2000). the effect of market orientation on product innovation. Journal of the Academy of Marketing Science28 (2), 239-47.

[23] Bennett, R.C., \& Cooper.R.C. (1981). "The misuse of Marketing: An American Tragedy”, Business Horizons, 24 (6): 51-61.

[24] Christensen, C.M. and Bower, J.L. (1996) .Customer Power, Strategic Investment and the Failure of Leading Firms. Strategic Management Journal, 17, 197-218.

[25] Slater, S.F. and Narver, J.C. (1994a) .Does competitive environment moderate the market orientation-performance relationship? Journal of Marketing 58, January, 46-55.

[26] Slater, S.F. and Narver, J.C. (1994b). Market orientation, customer value, and superior performance. Business Horizons37, March-April, 22-8.

[27] Baker, W. E., and Sinkula, J. M. (1999a). "The Synergistic Effect of Market Orientation and Learning Orientation on Organizational Performance," Journal of the Academy of Marketing Science, 27 (Fall), 411-27
[28] Pelham, Alfred M, and David T, Wilson. (1996). "A LongitudinalStudy of the Impact of Market Structure, Firm Structure, Strat-egy, and Market Orientation Culture on Dimensions of SmallFirm Perfonnance," Journal of the Academy of Marketing Sci-ence, $24(1), 27-A 3$.

[29] Szymanski, D.M. and Henard, D.H. (2001) .Customer Satisfaction: A Meta-Analysis of the Empirical Evidence. Journal of the Academy of Marketing Science, 29, 16-35.

[30] Atuahene-Gima, K. (1996). Market Orientation and Innovation. Journal of Business Research, 35, 93-103.

[31] Hultink, Erik (1998). Launch decisions and new product success: an empirical comparison of consumer and industrial products VL - 17 Journal of Product Innovation Management

[32] Deshpandé, J. U. Farley. (1998)."Factors Affecting Organizational Performance: A Five-Country Comparison," Amos Tuck School, Dartmouth College, Working Paper.

[33] Baker, W. E., and Sinkula, J. M. (1999a). “The Synergistic Effect of Market Orientation and Learning Orientation on Organizational Performance,” Journal of the Academy of Marketing Science, 27 (Fall), 411-27.

[34] Atuahene-Gima, K. (1995). An Exploratory Analysis of the Impact of Market Orientation on New Product Performance. Journal of Product Innovation Management, 275-293. http://dx.doi.org/10.1016/0737-6782(95)00027-Q

[35] Rogers, E.M. (1983). Diffusion of Innovations. Free Press, New York.

[36] Hubert Gatignon and Thomas S Robertson. (1985). A Propositional Inventory for New Diffusion Research, Journal of Consumer Research, 11(4), 849-67

[37] Henard, David Szymanski, David.( 2001).Customer Satisfaction: A Meta-Analysis of the Empirical Evidence VL - 29 16-35, Journal of the Academy of Marketing Science

[38] M. Montoya-Weiss, Roger Calantone.(1994).Determinants of new product performance: A review and meta-analysis Determinants of new product performance: A review and meta-analysis Journal of Product Innovation Management 11,397-417

[39] Maidique, Modesto A. and Zirger, Billie Jo, A Study of Success and Failure in Product Innovation: The Case of the U.S. Electronics Industry (1984). IEEE Transactions on Engineering Management, EM-31, 4, 192-203 1984. Available at SSRN: https://ssrn.com/abstract=150635

[40] Song, M., \& Parry, M. E. (1996). What separates Japanese new product winners from losers? Journal of Product Innovation Management, 13(3), 1-14

[41] Cooper, R. G. (1979). The dimensions of industrial new product success and failure. Journal of Marketing, 43(2), 93-103.

[42] Cooper, R. G., \& Kleinschmidt, E. J. (1987). New products: What separates winners from losers? Journal of Product Innovation Management, 4(3), 169-184

[43] Song, M., \& Parry, M. E. (1997a). The determinants of Japanese new product successes. Journal of Marketing Research, 34(1), 64-76.

[44] Song, M., \& Parry, M. E. (1997b). A cross-national comparative study of new product development processes: Japan and the United States. Journal of Marketing, 61(2), 1-18.

[45] Harrington J.W, Green et al. (1995), Strategy formulation, organizational learning, and location New Technology and Regional Development, 2003

[46] Griffin, A. (1992). Evaluating QFD's use in U.S. firms as a process for developing products. Journal of Product Innovation Management, 9(3), 171-182

[47] Kohli, A. K., \& Jaworski, B. J. (1990). Market orientation: the construct, research propositions, and managerial implications. Journal of Marketing, 54(2), 1-18.

[48] Griffin, A. H., \& Robben, H. S. J. (1997). Industrial new products launch strategies and product development performance. Journal of Product Innovation Management, 14, 243-257.

[49] Terwiesch, Christian, and Christoph H. Loch. "Measuring the Effectiveness of Overlapping Development Activities." Management Science, 45, 4, 1998, 455-465. JSTOR, www.jstor.org/stable/2634817.

[50] Cooper, D.R. and Schindler, P.S. (2003).Business Research Methods. 8th Edition, McGraw-Hill Irwin, Boston. 